\title{
An Interpretative Phenemenological Analysis of The Twenty Years of Indonesian Political Reform: Ideals, Expectations, and Challenges
}

\author{
Ujang Komarudin', Galuh Dian Prama Dewi \\ \{ukom.ui@gmail.com¹, galuh.dewi@binus.edu²\} \\ ${ }^{1}$ International Relations Department, Universitas Al Azhar Indonesia, Jl. Sisingamangaraja No. 2, \\ Selong, Kebayoran Baru, Kota Jakarta Selatan, Jakarta 12110, Indonesia. \\ ${ }^{2}$ International Relations Department, Universitas Bina Nusantara, Jl. Kemanggisan Illir II No. 45 \\ Kemanggisan - Palmerah Jakarta Barat 11480, Indonesia
}

\begin{abstract}
This study aims to analyse the strengths and weaknesses of politics and governance of Indonesia to realise the ideals of the Indonesian nation and acquire a pivotal role at the international level. The seventy-two years of Indonesia's independence and the twentieth anniversary of Indonesia's reforms have made Indonesia an influential country in conducting democracy and active participation in global governance. By applying qualitative method with Interpretative Phenomenological Analysis (IPA) and data collection method through interview, observation and document studies, this study found that since post-1998 reforms Indonesia has experienced changes in the management of government systems. Although twenty years of reform has given birth to "ideal" leaders working for people, nation, and state, yet corrupt system and governance conditions become a challenge of their own that forces leaders to work even more extra for the sake of achieving clean government.
\end{abstract}

Keywords: Indonesia, Reforms, Interpretative Phenomenological Analysis (IPA), Democracy.

\section{Introduction}

At the age of 20 years of reform, Indonesia does not seem to have succeeded in achieving the goals of reform. Political elite still relies on individual, group and party interests. The essence of reform better changes that occur in all sectors of life. Elites and power hunters should not use reform as a strategy to perpetuate power and increase their wealth.

One of the inhibiting factors in Indonesia's reform process is the elite character. Habitus or habit, to borrow a phrase from Pierre Bourdieu, habitus elite that does not want to change and do not want to leave the comfort of living [1]. Negative characteristics such as corruption in the New Order era continued to occur and even more massive in the reform era. Corruption which in the New Order era focused on Soeharto's internal power, moreover, in the reform era spread in almost all state institutions and bureaucracy. The 1998 Reform was hope for improvement for all the people of Indonesia. The essence of the reform is to change towards a better direction. This research aims to explore and interpret the phenomenology which focused on how people's experiences, "life worlds" and underlying assumptions (as in the Husserl's concept) on the twenty years of Indonesian political reform post-1998. 


\section{Power Transition and Democratization}

The relationship of power with politics lies in the ability to produce voluntary loyalty, and the ability of the power to govern and enforce compliance. Loyalty and voluntary are the ideal traits for every power [2]. The success of the New Order for 32 years because of the ability to manage power by maintaining the loyalty of community and coercion. However, at the same time, authoritarian and despotic power will only harm the people, with the result that the power will gradually fall and replaced to more democratic. The reform that took place in 1998 was a form of popular resistance to the power of the New Order. The age of 20 years is the continuation of Indonesia's democratic transition. A consolidated democratic change will put forth a democratic government. However, a democratic transition that does not go according to its path will restore Indonesia to authoritarianism.

Although the post-World War era has increased the possibility of a "new international order" based on expanding democracy throughout the world and expanding the spirit of new cooperation and peace, however, the enthusiasm that made this possibility welcomed now seemed to shift far. The crisis in Palestine and the Rohingya of Myanmar, Iraq, Bosnia, Somalia, Rwanda and other places are the challenges to the creation of a government and international democratic culture [3]. Indonesia seems to experience the same development of democracy as the face of Asia. South Korea and Taiwan are among the countries that have achieved procedural democracy and entered the era of consolidation. Although, some countries in South Asia and Thailand have experienced a decline in freedom. Besides, several Asian countries have been through the momentum of transition from an authoritarian regime to democracy. However, the absence of basic democratic principles such as participation, representation and accountability threaten its electoral democracy. The political situation of several countries in Asia illustrates that the democratization does not improve the quality of life of the people. Asia teaches that the transition from authoritarianism is not always a democratic transition where the achievement of electoral democracy does not necessarily create representation and the transition to substantive democracy [4]. The transition from nondemocratic governance to a democratic government is a complex process and involves some stages. Changes in the new regime often make democracy limited. Indonesia, twenty years of reform is still a way for the achievement of a stable democratic process.

\section{Method}

This study applied a qualitative approach with Interpretative Phenomenological Analysis (IPA). IPA is one qualitative method form that concerned with the detailed examination of individual lived experience and how individuals make sense of that experience [5] or explore in detail how participants are making sense of their personal and social world. IPA attempts to explore personal experience with an individual's perception or account of an object or event, as opposed to an attempt to produce an objective statement of the purpose or event itself [6]. Participant had experience of working within government (legislative level) and political parties. Language as raw material. The data collection method was through interviews and conversation with elite politics, newspaper articles, field notes. The observation process was held as a political observer and acquire the political situation and elite behavior. The interview result and observation were noted. Whereas, the document studies were from the books, journals, and newspapers that state elite's statement. This method emphasized description and understanding rather than explanation and prediction also the meaning of experience or behavior in context. 


\section{Indonesia Political Transition}

Democracy is a choice and a necessity. General elections are one of the characteristics of a democratic country. A democratic system is a system that practices free and fair elections [7]. Democracy is the nation's rational choice for a better Indonesia.

\subsection{The Political Reform}

In case, during the New Order the President and vice president were elected by the MPR, then since 2004 the president and vice-president even the House of Representatives, Parliament and local leaders are directly elected by the people. However, direct elections have consequences for expensive political costs. The high political prices that must be issued by political contestants, such as the president, vice president, legislative candidates - central and regional - and candidates for regional heads, have brought democracy to be "noisy". "The noise" occurred because of political dowry problems which later demanded the Corruption Eradication Commission capture elite political parties who were recommended to be candidates for regional heads because of corruption issues. In 2018, the KPK arrested 100 regional heads.

Election of regional heads with high costs makes prospective regional heads brave enough to sign development projects to entrepreneurs or practical economic elites. Furthermore, the entrepreneurs will provide capital in the future, and in return, the elected regional head will give the project in the budget to the entrepreneur. The high cost of election costs is a dilemma in the hope of finding the best leaders at the central and regional levels. Chairperson of the Indonesian Parliament blamed the high cost of direct election politics, which is the root of the problem of regional heads committing criminal acts of corruption [8].

The 1998 reformation has encouraged an increase in the proliferation of political parties in Indonesia. The development of complex societies has made leaders, and political elites compete to establish political parties. It makes sense and is rational if political parties emerge from the fall of Soeharto from the throne of power. The political parties during the New Order under the Suharto regime, there were only three parties: Golkar, PDI, and PPP however, since reform the political parties have grown steadily. The election in 1999 became the first election in the reform period and produced 48 political parties. The poll ran democratically, and there was no bloodshed. The 1999 election has also become an important milestone in the reform era which resulted in fundamental changes in the state order. However, current political parties tend to strengthen party oligarchy, where a group of people controls a political party for a particular purpose [9]. Political elite still dominates political parties in Indonesia.

MPR members from the 1999 General Election made a breakthrough by amending the 1945 Constitution. From 1999 to 2002, the MPR members made four changes to the 1945 Constitution. The president who was initially elected by the MPR was changed and elected directly by the people. The Indonesian House of Representatives that has just become an executive label then has turned to a super agency that has broad authority. The DPD of the Republic of Indonesia also exists as a representation of non-political (independent) party figures. According to Amien, the amendments to the 1945 Constitution had a positive impact. One of them is the presidential election. If the word returned to the 1945 Constitution before the reform, the president could be chosen many times without being able to be changed. And if it returns before the amendment, regional autonomy will disappear so that there will be centralization of power[10].

The 2004, 2009 and 2014 general elections became a separate history, in which the Indonesian people for the first time in 2004 directly elected their president and deputy. 
Elections were not through representatives in the MPR as happened in the previous era. In 2004, for first Indonesia was meeting a political drama when the fall of Megawati Soekarnoputri arrived by her minister Susilo Bambang Yudhoyono (SBY). In 2004 election SBY became the winner off drama president election, and the Democratic party became the ruling party. Reformation has provided an opportunity for anyone to gain power constitutionally.

Direct presidential elections have changed the face of Indonesian partisan politics from setting the president's victory, becoming the elected president of the people. Policies in the form of direct presidential elections make sovereign people have the right to decide who their leaders are.

In the 2004 election, Golkar became the winning party. However, in 2009 the championship was replaced by the Democratic Party and PDI in 2014. During the three elections, the winning party seemed to change and varied. This diversity shows that voters have full power to choose the party they like. Parties which fight for people's aspirations will be the people's choice. Likewise, the party that betrays the people, in time they will leave them. The differences in the political winners in each election indicate that there are no loyal voters. Voters can be influenced and determined by the problems championed by political parties.

On April 17, 2019, for the first time in its history, Indonesia will vote simultaneously in the presidential and legislative elections. The big celebration of the five-yearly democratic party is a party to look for presidents and vice presidents in one package, members of the DPR, DPD, Province, and Regency / City. Simultaneous selection is also not only to save the budget but also to streamline candidates in their ballots. With the result that people don't need to be reversible to the polling stations in every political contest.

In the future, Indonesia needs to develop electronic-based elections or elections through evoting. As a form of realization of a modern democratic state, the government need to built electoral methods. With voters as much as 192 million more who have right to vote in 2019, it will be more effective and efficient through e-voting, so that the allocation of costs will be lower, simple, and follow the changing times with the emergence of the 4.0 Industrial Revolution. Democracy can take advantage of digital technology and automation in elections. Voting electronic systems or e-voting should conduct in the 2019 presidential and legislative elections because it has many benefits. The infrastructure and technology already exist and our telecommunications infrastructure is far better than Philipina (who has e-voting) [11].

Campaigns against each other and bring down one another still colouring the competition between the Presidential and Legislative elections. The development of narratives by the second party does not yet contain a substantial campaign, the vision, mission, and best programs of each candidate. People are waiting for a vibrant battle, creative and innovative campaigns that encourage the community, quality like the great leadership of Indonesia's future. Large Indonesian ships cannot be led by figures whose visions are unclear, because nations that do not have clear images will be destroyed [12]

Political parties need internal maintenance and the building of strong cadres. Political parties need to reform themselves and become one of the arenas to be able to influence the old paradigm of elites and organisations. The old model tends to perpetuate oligarchy and dynasty through political regeneration, placing as much material profit as possible, an arrogant style that manages to sacrifice the interests of the people.

One of the sources of the destruction of the party system in Indonesia is material elements. People become part of political parties because they want to gain power and multiply money and assets. If there is no improvement in the party, then what will happen is massive corruption. The performance of political parties is still disappointing because there 
are still many cadres who trapped in corruption cases. Political parties need to be reformed to carry out their constitutional duties. Democratic transitions must be better, healthier, and so that KPK arrest operations will decrease [13].

The signing of the KPK's Political Party Integrity Pact (PIPP) is an excellent start to reform the body of political parties. However, if these steps are merely ado, only to get the sympathy of the people, then there will be no change at all. KPK Chairman invited all political parties in Indonesia to ask for support from political parties so that democracy would be better [14].

\subsection{The Legislative and the Executive}

The legislature is a manifestation of the implementation of reforms in political parties. After the 1998 reforms, Parliament has greater authority in carrying out its duties and has become a strong representative body. The existence of this extraordinary authority requires control of the institution. There is no free lunch! In making laws, if there is no lunch provided, so there is no draft issued by Legislation (National Legislation Program). In producing the legal authority of the law, there will be people who are looking for loopholes to gain profits.

Legislative power has made Parliament also have the right to travel abroad on the grounds of comparative studies. But unfortunately, productivity remains low and wasted budget. The minimum law produced and ratified due to a large number of visits by RI DPR members abroad. For productivity to increase, members of the House of Representatives are forbidden to study overseas [15]. $\mathrm{n}$ budgeting duty, DPR has the authority to discuss and approve the budget of each ministry and agency. This authority in another hand has made Parliament more prosperous. Power is a way for every leader or bureaucracy in the department to lobby Parliamentarians to pass budgets in their respective ministries. This opportunity provides a gap for members of the House of Representatives to conspire with departments and agencies that want budget approval. Before reform, the executive budget was in the hands of the executive, but when political changes occurred, budgetary authority and supervision were in the legislative duties.

Supervision is one aspect of management, planning, organization, implementation, and evaluation. Management aspects are closely related to efforts to achieve organizational goals such as the state. The monitoring function implies whether an activity to achieve the objectives has been carried out based on the provisions made [16]. Reforming parliamentary institutions is a necessity. The implementation of bureaucratic reform was not as easy as turning a palm. The reform requires the commitment of all parties. The bright bureaucracy will make difficulties for politicians, especially in the procurement of goods and all kinds of things [17]. Bureaucracy must be professional in the task of state administration and public service. Bureaucratic professionalism is entirely an encouragement and step for every bureaucratic apparatus. The system needs to run based on achievement and competence. The politicization of bureaucracy in the practical political arena for a while can destroy the desired professional administrative order [18].

\section{The Rising Power of Non-Government and Parliamentary People}

The emerging of political forces from the community such as the GNPF-MUI which was fronted by Habib Rizieq Shihab (HRS), Bachtiar Natsir, etcetera marked Indonesian reform. The success of the action 212 on demand for justice over the case of the AL Maidah 51 defamation, prompted the act of criminalisation of Islamic religious leaders, one of which was 
the arrest of HRS in Saudi. Action 212 shows that reforms have resulted in the freedom of people to gather and express their opinions in public.

\subsection{Legal Reform}

Law enforcement is a necessity in democratisation. Law may not be a tool of power or to secure themselves and their groups. The primary cause of the collapse of a nation is corruption, in addition to not upholding law and justice [19]. Law no longer becomes commander when politics collaborates with the economy. Many politicians only use the law as a tool of power and business people as interests [20].

The reformation has led to an independent law enforcement agency, the Corruption Eradication Commission (KPK). The public's expectation of the KPK has made the KPK work professionally and dedicated to the interests of the nation and the state. Because of the KPK's hard work in fighting corrupt officials, it is not surprising that the KPK often experiences criminalization. One of the investigators, Novel Baswedan, was watering hard water. This action shows the absence of guarantees of protection and safety of law enforcement by the state. An indication of case freezing is a dangerous precedent for anti-corruption and the rule of law in Indonesia. The shadow of threats from outsiders who attack physically and nonphysically to KPK law enforcement can happen anytime.

Finding and arresting the perpetrators of watering the Novel Baswedan is a government obligation and a test of police professionalism and the objectivity of law enforcement. Opening and communicating the truth to the public, as well as giving justice to the perpetrators is as essential as eradicating corruption itself. As the primary law enforcement agency, the police must be a leader, clean, honest and fair in the process of law enforcement and eradicating corruption in Indonesia. Therefore, legal organizations require internal improvements.

This nation needs the commitment of all components of society and law enforcement officials to work professionally for the sake of the country and the state. Twenty years of reform, Indonesian law enforcement has not been consistent. Politics is still a commander in this country. The elements of law enforcement agencies such as the police, the Constitutional Court, the Supreme Court, and the courts must be prepared to bring this nation into a nation free from corruption. Twenty years of reform and seventy-three years of independence, Indonesia needs more synergy and cooperation, especially between the KPK and the police. Mutual support is the best way to rid Indonesia of corruption. A rich country is a country that has officials working for people's welfare and nation-building. If the law enforcement agencies are clean, the law enforcement process will run well.

\subsection{Economic Reform}

Economics is an essential foundation for the survival of a country. The fall of the New Order regime and move to reform was a result of economic shocks which caused a weakening of the rupiah. Financial stability is a guarantee for the power of a system. The resilience of the New Order Regime for thirty-two years was due to stable economic support, a sense of security and pleasurable in the community. The collapse of the New Order occurred because the government could not anticipate economic instability and other political problems.

In the SBY era, the Direct Cash Assistance (BLT) program became a form of government subsidy for the poor while the Jokowi era adopted BLT through the Hope Family Program (PKH) with the aim of helping low-income families to meet the learning expectations of poor children and maintain people's purchasing power. 
Indonesia's small economic actors and the purchasing power of the lower middle economic community are the driving agents of the Indonesian economy. The government has devoted a lot of populist economic programs, one of which is the People's Business Credit (KUR). KUR is a scheme of government capital grants through banks to build the economic foundation of small businesses. According to Jokowi, PKH is very important to keep children from low-income families in school, have proper nutrition so that they become intelligent children, and can maintain the economy [21]. The existence of KUR shows the shape of the state present in the Pancasila democratic economy [22].

Twenty years of reform, Indonesia also faces an increase in national debt which in time can destabilize the country's economy and the destruction of the country. The habit of being indebted without encouraging the optimization of internal capabilities to be independent will make the republic slow in building. Reformation hopes the state can resolve debt problems and remain committed to periodic development.

\subsection{Media Reform}

Media is a pillar of democracy. If during the Soeharto era there were space restrictions on the media, then after the reform the press found its independence. At the same time, change has also created a lack of control over news broadcasting. Although the media get professional assignments to provide information quickly, accurately, and objectively to the public, at the same time, media owners have alignments and self-image agendas and their political interests. Although the arrangement of media owners with individual candidates in the presidential election is legal, it is a private right and is guaranteed legally, but the media must still be able to provide correct information to the public.

Democracy requires openness, transparency and objectivity in sharing information. Political interests have now bound the Press, one of its functions to educate the public. The mass media in Indonesia is currently heavily contaminated by the politics and affairs of media owners, especially news television [23].

A free press should educate, enlighten, and bring good values. Freedom does not mean spreading arbitrarily and giving lies or to marginalize political opponents and positively portray specific presidential candidates. The press must also be open to criticism, contribute to the progress of democracy, maintain unity and security, independent and impartial. Politicians who have mass media to be fair and not intervene in their editorial for political interests. The press manager should maintain integrity and be independent in conducting general election coverage. The press, especially television, must be fair, guarding the fire fence by separating the newsroom and business space. Intervention to the editorial room is not only disgraceful and violates the journalistic code of ethics, however has the potential to break the law [24]. The media must be able to control a government that does not work for people.

Media is one indication of national civilization. The law also needs to guarantee security protection for media workers. In 2003, protests against the Tempo magazine through demonstrations, oppression, and even violence, have caused a journalist and editor-in-chief to be injured [25]. Destruction of all forms against journalists is not justified. Expectations for media reform in addition to objectivity, transparency, openness in the delivery of news, hopes of change are also able to provide security for news providers in working for the public.

\subsection{Environmental Reform}

Environment requires individual responsibility and attention for all citizens. Environmental problems can be a political problem. The mandate of reform lies not only in political democracy but also in ecological justice through responsibility for its preservation to 
create a safe, comfortable, peaceful and orderly society. Environmental reform requires that the management of vast industrial natural resources in Indonesia do not carry out activities that disrupt the habitats of humans, animals and plants. The government will increasingly spawn populist programs for political interests and carry out policies that harm the people. On the one hand, the government presents a reformist and environmentally friendly face. On the other hand, the government is increasingly repressive, such as the expulsion of citizens on their land which is the wrong side of the government in dealing with environmental problems. Meanwhile, corporations are also the rulers of spatial planning [26]. Mining exploration by companies that do not maintain ecological sustainability or bribery for permits for Environmental Impact Assessment (EIA). As in the case of corruption of Lippo officials to the Regent and Head of the Bekasi Office regarding environmental licenses.

Environmental politics combines environmental problems with politics. Politics is a tool to be able to keep the environment stable and safe. Various political contestants consistently aim at ecological issues as a political agenda.

\subsection{Indonesia's Role in World Peace}

Indonesia remains consistent in fighting for Palestinian independence and helping the Rohingya people in Myanmar. Justice for the Rohingya is a humanitarian problem, not just a regional issue. The law must process acts of cruelty by the Myanmar government [27]. Twenty years of reform have provided space to be actively involved in creating a peaceful world order. Improvement must overcome change not only domestically, but also must be able to change the international world order to be quieter, free from all forms of oppression and discrimination.

Table 1. Summary of Findings Pre and Post-Reform 1998

\begin{tabular}{|c|c|}
\hline Pre-Reform 1998 & Post reform 1998 \\
\hline Closed and authoritarian politics & Openness of the politics. \\
\hline $\begin{array}{l}\text { Electoral conditioning, no press freedom, } \\
\text { freedom to express opinions. }\end{array}$ & $\begin{array}{l}\text { Unlimited freedom (press, expression and } \\
\text { association), enforcement and weak legal } \\
\text { instruments. }\end{array}$ \\
\hline $\begin{array}{l}\text { Power concentrated in one person, } \\
\text { president. }\end{array}$ & Power in certain groups \\
\hline No checks and balances. & Checks and Balances. \\
\hline $\begin{array}{l}\text { Power tends to be corrupt and tends to } \\
\text { produce corrupt state administrations. }\end{array}$ & $\begin{array}{l}\text { Open, direct, election for president, DPR, } \\
\text { DPD, DPRD and corruption in national and } \\
\text { local administrations. }\end{array}$ \\
\hline $\begin{array}{l}\text { The legislature is only an executive } \\
\text { stamp. }\end{array}$ & $\begin{array}{l}\text { Implementation of the } 1945 \text { Constitution } \\
\text { Amendments, parliament has power in } \\
\text { Legislation, Budgeting and Supervising, } \\
\text { parliament and executive in the same level. } \\
\text { Active in defending the independence of the }\end{array}$ \\
\hline $\begin{array}{l}\text { Free active political diplomacy and } \\
\text { active involvement in world peace } \\
\text { missions. }\end{array}$ & $\begin{array}{l}\text { Palestinian people and assistance to } \\
\text { Rohingya. } \\
\text { The establishment of the KPK }\end{array}$ \\
\hline Stable economy and security & \\
\hline
\end{tabular}




\section{Conclusion}

Twenty years of reform, Indonesia requires to build optimism in reestablishing reform aspirations that can turn this nation into a better direction. Reform has changed the policies and directions of the Indonesian parliament to become more modern, fenceless, and aspirational. Media reform has opened up the freedom of the press. Freedom has consequences for the media's excessive attitude in gathering and reporting news. Even though there is freedom, the press must also keep up with the applicable rules. Media requires demands of the professional press to build democracy and control arbitrary government. On the contrary, reform in law remains unable to resolve legal issues in Indonesia. Law is merely an instrument for oppressing, protecting interests and certain frightening parties. Constitutional reform should be refer to the values of professionalism in law enforcement circles.

\section{References}

[1] Takwim, Bagus, Resistensi Gaya Hidup: Teori dan Realitas, Jalasutra, Yogyakarta: Jalasutra, 2006, pp. 35-54.

[2] Carter, April, Otoritas dan Demokrasi, Jakarta: CV Rajawali, 1979, p. viii.

[3] Held, David, Demokrasi dan Tatanan Global: Dari Negara Modern hingga Pemerintahan Kosmopolitan, Jakarta: Pusataka Pelajar, 2004, p. 338.

[4] Irwansyah, "Indeks Demokrasi Asia 2011: Potret Indonesia," Jurnal Studi Politik. Demokrasi Bukan Sekedar Prosedur, vol. II, no. 1, 2012.

[5] Eatough, Virginia \& Jonathan A. Smith, Qualitative Research in Psycology, vol. 1, Stainton-Rogers, Carla WIllig and Wendy, Ed., London: Sage Publication Ltd, 2008, p. 1.

[6] Smith, A. Jonathan \& Mike Osborn, "Doing Social Psychology Research," 2004. [Online]. Available: https://doi.org/10.1002/9780470776278.ch10. [Accessed December 2018].

[7] Cee, Chan Heng, Demokrasi Kapitalisme: Perspektif Asia dan Amerika, Jakarta: CIDES, 1994, p. 2.

[8] Soesatyo, Bambang, Interviewee, [Interview]. 4 November 2018.

[9] O'rourke, Kevin, Reformasi: The Struggle for Power in Post-Soeharto Indonesia, Australia: Allen \& Unwin., 2002, p. 197.

[10] Rais, Amin, Interviewee, [Interview]. 21 Mei 2017.

[11] Effendi, Sofian, Interviewee, [Interview]. 23 January 2018.

[12] Roosevelt, Franklin D, Dalam buku Pidato-pidato yang Mengubah Dunia: Kisah dan Petikan Pidato-pidato Bersejarah, Jakarta: ESENSI Airlangga Group, 2006, p. 103.

[13] Haris, Syamsuddin, Interviewee, [Interview]. 7 August 2018.

[14] Raharjo, Agus, Interviewee, [Interview]. 4 December 2018.

[15] Komarudin, Ade, Interviewee, [Interview]. 18 January 2018.

[16] Fatwa A.M, Melanjutkan Reformasi Membangun Demokrasi: Jejak Langkah Parlemen Indonesia Periode 1999-2004, Jakarta: PT Raja Grafindo Persada, 2006, p. 207.

[17] Prasojo, Eko, Interviewee, [Interview]. 20 December 2018.

[18] Firnas, Adian M., Journal Review Politik, vol. 06, no. 01, p. 165, June 2016. 
[19] Mahfud, MD, Interviewee, [Interview]. 27 December 2018.

[20] Asshiddiqy, Jimly, Interviewee, [Interview]. 18 January 2018.

[21] cnnindonesia.com, 19 January 2019. [Online].

[22] Marleni, Siska, Interviewee, [Interview]. 28 April 2016.

[23] Prasetyo, Yosep Stanley, Interviewee, [Interview]. 20 January 2016.

[24] Manan, Bagir, Interviewee, [Interview]. 18 march 2014.

[25] Sadono, Bambang, Jalan Tengah Mengawal Reformasi, Jakarta: Yayasan Dana Sejahtera Mandiri, 2006, pp. 233-235.

[26] Hidayati, Nur, Interviewee, [Interview]. 18 January 2018.

[27] Sundari, Eva Kusuma, Interviewee, [Interview]. 24 August 2018. 